\title{
A Sensitive and Selective GC-MS Method for Analysis of Genotoxic Impurities in Dobutamine Hydrochloride
}

\author{
VIJAYA LAKSHMI.MADDALA ${ }^{* 1}$, P.C.RAY ${ }^{1}$ and KMVN RAO ${ }^{1}$ \\ ${ }^{1}$ Inogent Laboratories Private limited. \\ ${ }^{*}$ Corresponding author E-mail: Vijaya_chem @yahoo.com \\ http://dx.doi.org/10.13005/ojc/320347
}

(Received: April 06, 2016; Accepted: May 27, 2016)

\begin{abstract}
A sensitive GC-MS method for analysis of residues of Methyl-p-toluene sulfonate [Fig.2], Ethyl p-toluene sulfonate [Fig.3] and Isopropyl p-toluene sulfonate [Fig.4] Genotoxic impurities in Dobutamine hydrochloride [Fig.1] drug substance, has been developed and validated. Under the optimum conditions of the proposed method is specific, precise, linear, accurate and rugged. The response was linear in the concentration range of LOQ to $0.18 \mathrm{mg} \cdot \mathrm{g}^{-1}$ with correlation coefficients of greater than 0.99 for each impurity. Under the optimum conditions used for the sample preparation the recovery of each impurity is in between $78-108 \%$.
\end{abstract}

Keywords: Dobutamine hydrochloride, GC-MS, Genotoxic impurities, method validation.

\section{INTRODUCTION}

Genotoxic impurities have the tendency to cause a potential damage of the genetic material, for example DNA even at very low level of exposure. There are three primary effects that genotoxins can have on organisms by effecting their genetic information. Genotoxins can be carcinogens, or cancer causing agents, mutagens or mutationscausing agents or teratogens, birth defect causing agents. Thus, there is a high demand and need to identify the potential impurities that arise during synthesis, purification and storage keeping the damaging effects of Genotoxic impurities, many international regulatory agencies has already published the guidelines regarding the limits of Genotoxic impurities. Both EMEA guidelines and a phRMA propose a maximum of daily exposure target of $1.5 \mu \mathrm{g}$ per day genotoxic impurities in pharmaceuticals is recommended Based on the Threshold of toxicological concern (TTC), the concentration limits of the impurity in a drug substances or drug products can be derived based on the maximum daily dose: concentration $(\mathrm{ppm})=$ $[1.5 \mu \mathrm{g} / \mathrm{day}] /[$ dose $(\mathrm{g} / \mathrm{day})]$. For a drug dosed at $1 \mathrm{~g}$ per day, for example, $1.5 \mathrm{ppm}$ would be the limit of that specific Genotoxic impurity. 
Dobutamine hydrochloride ${ }^{1-2}$ is a sympathomimetic with direct effects on beta1- adrenergic receptors, giving it a prominent isotropic action on the heart. It also has some alpha - and beta2 - agonist properties. Although it is structurally related to dopamine it has no specific dopaminergic properties; however, like dopamine, the isotropic action of dobutamine on the heart is associated with less cardiac - accelerating effect than that of isoprenaline. Dobutamine is used to increase the contractility of the heart in acute heart failure, as occurs in cardiogenic shock and myocardial infarction. It is also used in septic shock. Other circumstances in which its isotropic activity may be useful are during cardiac surgery and positive end - expiratory pressure ventilation.

During the synthesis these are the three Genotoxic impurities present in the Dobutamine hydrochloride. Based on the literature survey, to the best of our knowledge there is no method to estimate of these Genotoxic impurities. Here in this paper we present a sensitive GC-MS ${ }^{3}$ method has been developed and validated for the estimation of Genotoxic impurities. The mentioned Genotoxic impurities are prepared and tested in Inogent Laboratories private limited, Nacharam, Hyderabad.<smiles>CC(CCc1ccc(O)cc1)NCCc1ccc(O)c(O)c1</smiles>

Fig. 1: Dobutamine hydrochloride<smiles>COS(=O)(=O)c1ccc(C)cc1</smiles>

Chemical Formula: $\mathrm{C}_{8} \mathrm{H}_{10} \mathrm{O}_{3} \mathrm{~S}$ Molecular Weight: 186.23

Fig. 2: Methyl p-toluene sulfonate

\section{EXPERIMENTAL}

Active pharmaceutical ingredient standards and samples were supplied by Inogent Laboratories private Limited, Hyderabad, India. The HPLC grade Toluene was purchased from Merck, Darmstadt, Germany.

\section{Chromatographic conditions and equipment}

Mutagenic impurities ${ }^{5-6}$ are separated by

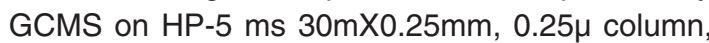
Samples and standards are prepared in $0.1 \%$ Diethyl amine in methanol in the system Agilent 7890B Gas chromatograph equipped with 5977A Mass selective detector. The oven programme consists of Initial the oven is programmed at $60^{\circ} \mathrm{C}$ for 3 minutes, then increased at the rate of $25^{\circ} \mathrm{C} / \mathrm{min}$ upto $250^{\circ} \mathrm{C}$, hold the temperature at $250^{\circ} \mathrm{C}$ for 10.5 minutes, Injector temperatue is put at $200^{\circ} \mathrm{C}$, Auxiliary temperature at $300^{\circ} \mathrm{C}$. The carrier gas is Helium(High purity $99.999 \%$ ), at a constant flow rate of $1.4 \mathrm{~mL} / \mathrm{min}$ and the split ratio is $1: 10$. having the injection volume 1.0 $\mu \mathrm{L}$, the total runtime of 21 minutes.

The Ion source in the mass spectrophotometer is the Electron impact ionization, in which the acquisition mode is SIM(Selective ion monitoring), having the source temperature at $230^{\circ} \mathrm{C}$ and quadrapole temperature at $150^{\circ} \mathrm{C}$, solvent delay time is put for 7 minutes. The SIM parameters are Group id is 1, high resolution and the ions/dwell time are 155/100, 172/100, 186/100, 200/100, 214/100.

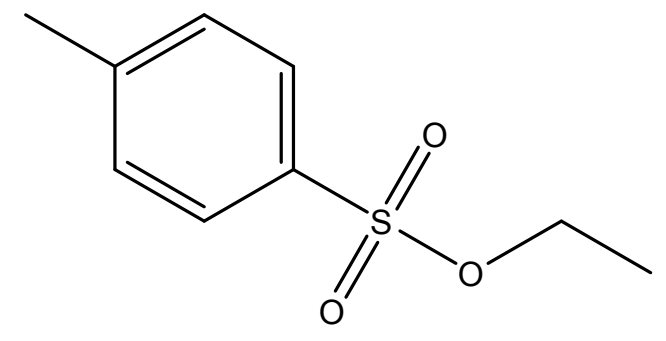

Chemical Formula: $\mathrm{C}_{9} \mathrm{H}_{12} \mathrm{O}_{3} \mathrm{~S}$ Molecular Weight: 200.25

Fig. 3: Ethyl p-toluene sulfonate 
Preparation of the stock solutions

An individual stock solution $\left(1000 \mu \mathrm{g} \cdot \mathrm{mL}^{-1}\right)$ of all impurities was prepared in diluent. Sample<smiles>Cc1ccc(S(=O)(=O)OC(C)C)cc1</smiles>

Chemical Formula: $\mathrm{C}_{10} \mathrm{H}_{14} \mathrm{O}_{3} \mathrm{~S}$ Molecular Weight: 214.28

Fig. 4: Isopropyl p-toluene sulfonate solution was prepared (10 $\left.\mathrm{mg} \cdot \mathrm{mL}^{-1}\right)$ in diluent. Limit of detection and limit of quantification for the impurities were evaluated by preparing the impurities in the level from $60 \mu \mathrm{g} \mathrm{mL}^{-1}$ to $150 \mu \mathrm{g} \mathrm{mL}^{-1}$. Linearity of each impurity is determined from LOQ level to 180 $\mu \mathrm{g} \mathrm{mL} \mathrm{L}^{-1}$.

\section{RESULTS AND DISCUSSION}

\section{Method development}

Method development was planned for the estimation of the above mentioned Genotoxic impurities in Dobutamine hydrochloride by using Gas chromatographic technique with mass spectrophotometer as detector, as evaluation limit was as low as $120 \mu \mathrm{g} \mathrm{mL}^{-1}$. Different columns with different stationary phases and dimensions were used like DB-624, DB-1, RTX-624 and RTX-1301 for

\section{System suitability chromatogram}
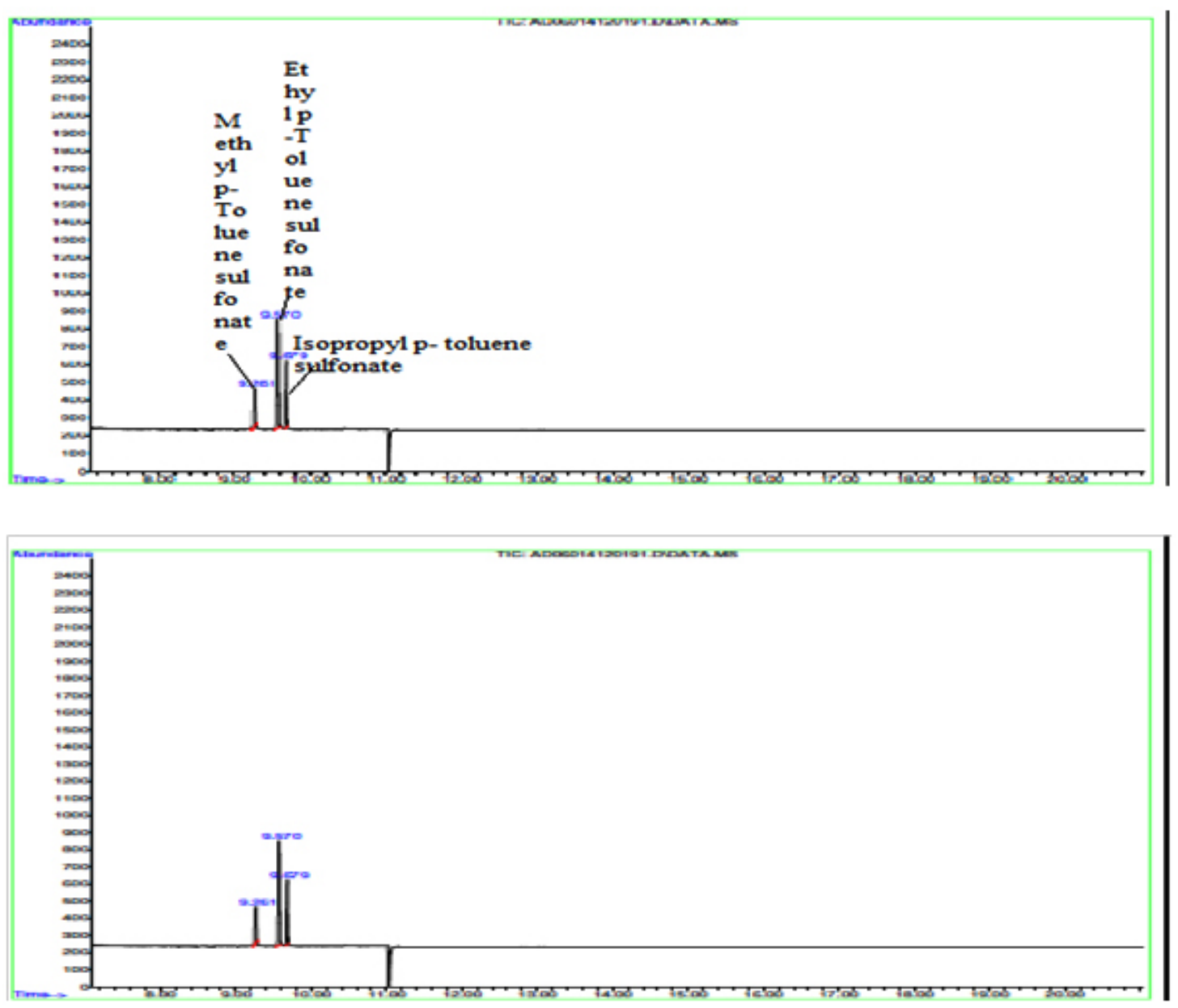
the analysis. Finally separation is achieved on HP-5 MS column, mid polar column with $5 \%$ phenyl and 95\% dimethyl polysiloxane as a stationary phase. During the method development using this column, appropriate separation is achieved between the impurities.

\section{Method validation}

Method validation ${ }^{11}$ activity was conducted with necessary parameters as per the analytical method validation guidelines of International conference on Harmonization.

\section{Blank chromatogram}

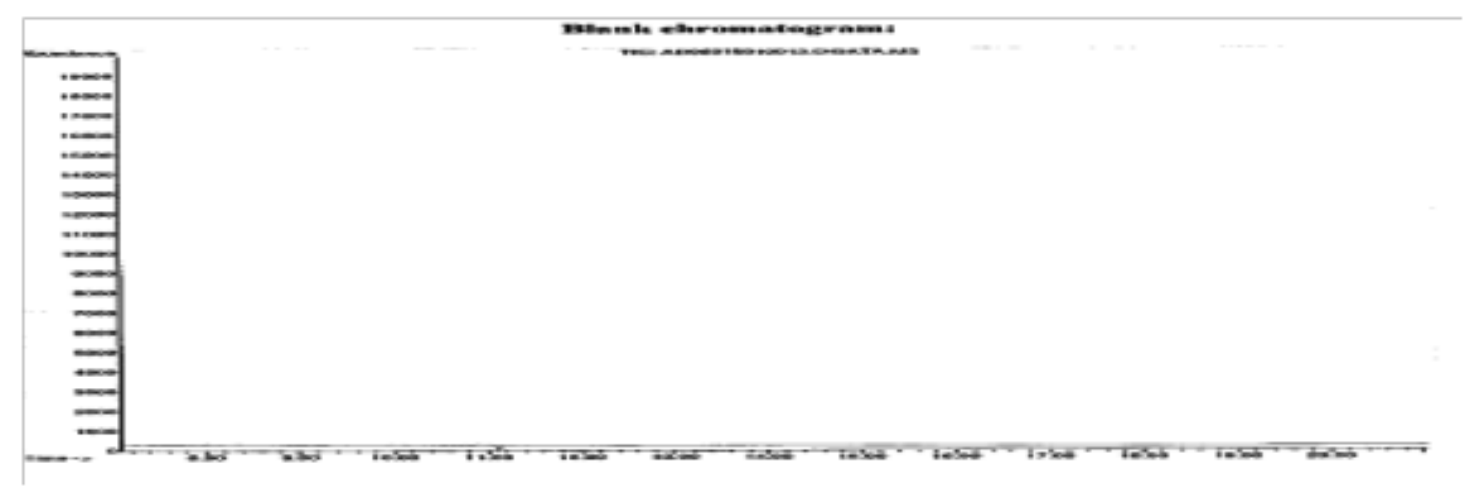

\section{Sample chromatogram}

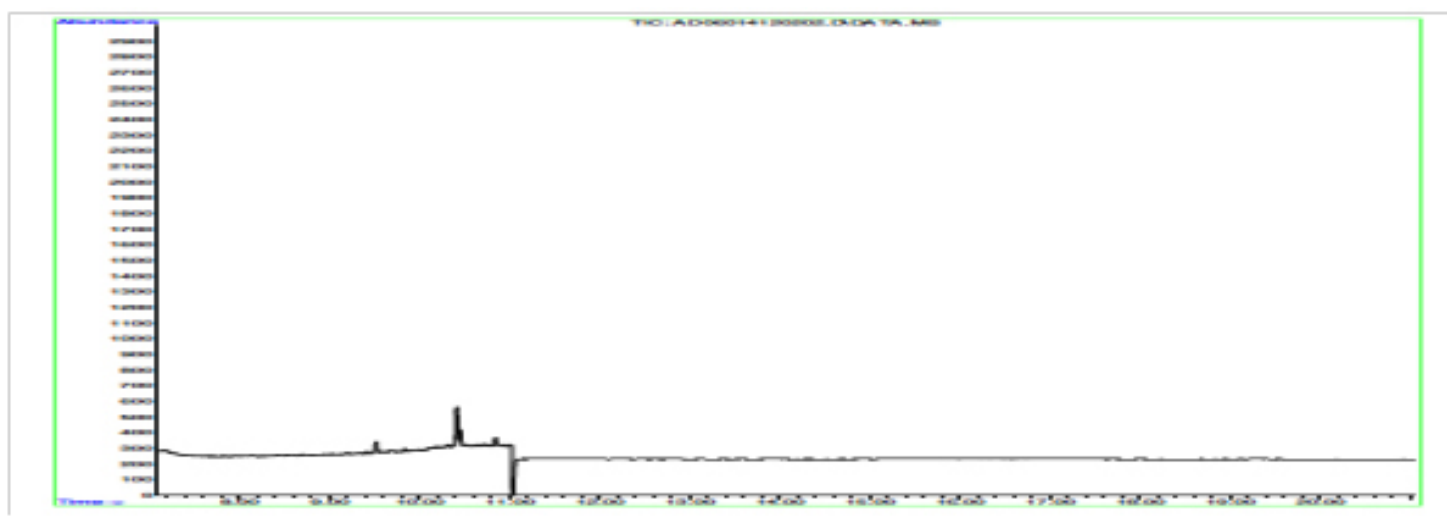

Table 1: LOD/LOQ

\begin{tabular}{|c|c|c|c|}
\hline LOD/LOQ & $\begin{array}{l}\text { Methyl p- toluene } \\
\text { sulfonic acid }\end{array}$ & $\begin{array}{l}\text { Ethyl p- toluene } \\
\text { sulfonic acid }\end{array}$ & $\begin{array}{l}\text { Isopropyl p- toluene } \\
\text { sulfonic acid }\end{array}$ \\
\hline Limit of quantification (ppm) & 13 & 8 & 12 \\
\hline Limit of detection(ppm) & 41 & 24 & 36 \\
\hline \multicolumn{4}{|c|}{ Table 2: Precision at limit of quantification level } \\
\hline Parameter & $\begin{array}{l}\text { Methyl p- toluene } \\
\text { sulfonic acid }\end{array}$ & $\begin{array}{l}\text { Ethyl p- toluene } \\
\text { sulfonic acid }\end{array}$ & $\begin{array}{l}\text { Isopropyl p- toluene } \\
\text { sulfonic acid }\end{array}$ \\
\hline$\%$ RSD for six preparations & 3.3 & 5.9 & 5.7 \\
\hline
\end{tabular}


Table 3: Linearity

\begin{tabular}{lccc}
\hline Parameter & $\begin{array}{c}\text { Methyl p- toluene } \\
\text { sulfonic acid }\end{array}$ & $\begin{array}{c}\text { Ethyl p- toluene } \\
\text { sulfonic acid }\end{array}$ & $\begin{array}{c}\text { Isopropyl p- toluene } \\
\text { sulfonic acid }\end{array}$ \\
\hline Correlation coefficient & 0.997 & 0.997 & 0.997 \\
Slope & 262.993 & 612.167 & 558.855 \\
Y-Intercept & 2746.472 & -525.528 & -6081.424 \\
\hline
\end{tabular}

Table 4: Accuracy

\begin{tabular}{lccc}
\hline Accuracy Level & $\begin{array}{c}\text { Methyl } \\
\text { p- toluene }\end{array}$ & $\begin{array}{c}\text { \%Recovery } \\
\text { E- toluene }\end{array}$ & $\begin{array}{c}\text { Isopropyl } \\
\text { p- toluene }\end{array}$ \\
\hline LOQ Level & 96.9 & 84.7 & 89.1 \\
$50 \%$ level(60 ppm) & 96.0 & 94.4 & 90.7 \\
$100 \%$ level(120 ppm) & 83.9 & 91.4 & 89.8 \\
$150 \%$ level(180 ppm) & 87.2 & 78.3 & 92.3 \\
\hline
\end{tabular}

Table 5: Method precision and Ruggedness

\begin{tabular}{lccc}
\hline Parameter & $\begin{array}{c}\text { Methyl } \\
\text { p- toluene }\end{array}$ & $\begin{array}{c}\text { \%Recovery } \\
\text { Ethyl } \\
\text { p- toluene }\end{array}$ & $\begin{array}{c}\text { Isopropyl } \\
\text { p- toluene }\end{array}$ \\
\hline $\begin{array}{l}\text { Method precision \%RSD } \\
\text { for six preparations } \\
\text { Ruggedness \% RSD } \\
\text { for six preparations }\end{array}$ & 4.5 & 2.7 & 3.2 \\
\hline
\end{tabular}

\section{Specificity}

Specificity is done satisfactorily by checking the all impurities individually and with spiked solution, confirmed that there is no interference of any impurity.

\section{Limit of detection (LOD) and Limit of Quantification (LOQ)}

The LOD and LOQ values for each impurity were predicted by using the series of solutions from $60 \mu \mathrm{g} \mathrm{mL}^{-1}$ to $150 \mu \mathrm{g} \mathrm{mL}^{-1}$ by using standard deviation of the response and slope method. The limit of detection and limit of quantification results are as shown below table-1. The method is precise at Limit of quantification level. The respective results are represented in below table-2

\section{Linearity ${ }^{9}$}

Linearity of the three impurities were satisfactorily done. A series of solutions were prepared at test concentration levels from around LOQ level to180 $\mu \mathrm{g} \mathrm{mL}^{-1}$ level. The peak area versus concentration data was done by linearity plot slope, intercept and residual sum of squares analysis. The calibration curve given based on response over the concentration range of the impurities. The results are tabulated in table-3

\section{Precision}

The precision ${ }^{8}$ of the developed method was checked by preparing the solutions by spiking the impurities at $100 \%$ level $\left(120 \mu \mathrm{g} \mathrm{mL}^{-1}\right)$ with the drug substance for six times to show that the system is precise. The \%Relative standard deviation of the 
areas at each level is less than $8 \%$ confirming the good precision. The method is also proved as rugged by analyzing the same with different column and different analyst on different day. The results are represented in table-5

\section{Accuracy}

The accuracy of the method was evaluated in sample solutions were prepared in triplicate by spiking all impurities at LOQ level, $60 \mu \mathrm{g} \mathrm{mL}^{-1}, 120$ $\mu \mathrm{g} \mathrm{mL} \mathrm{L}^{-1}$ and $150 \mu \mathrm{g} \mathrm{mL}^{-1}$. The $\%$ recoveries of the impurities are in table-4.

\section{ACKNOWLEDGMENTS}

The author grateful to Inogent Laboratories private Limited for providing the necessary facilities during the course of investigation.

\section{CONCLUSION}

In this paper a sensitive specific, accurate, validated and well defined GC-MS method for the quantification of Genotoxic impurities in Dobutamine hydrochloride at ppm level was described. The described method is highly reliable technique for the quantification of impurities present in the Dobutamine hydrochloride.

\section{REFERENCES}

1. Thippani ramesh, Nageswararao pothuraju, Ramisetty Nageswararao, saida shaik, Journal of pharmaceutical analysis, 2013, 3 434-439.

2. Kondamadgu S, Gandu V. Quantification of Drugs and Pharmaceuticals Using $\mathrm{N}$-Bromosuccinimide and Methyl. Orient $J$ Chem 2016;32(1).

3. Sahil K, Prashant B, Akanksha M, Premjeet S, Devashish R ()GC-MS: Applications. International Journal Pharma \& Biological Archives 2011 2: 1544-1560.

4. Senthamil Selvan P, Veeran Gowda K, Mandal U, SamSolomon WD, Pal TK, J Chromatogr B, 2007, 858, .,143-150.

5. Kamila MM, Mondal N, Ghosh LK, Gupta BK, Pharmazie, 2007, 62,486-487.

6. Maurer $\mathrm{HH}$, Tenberken $\mathrm{O}$, Kratzch $\mathrm{C}$, Weber AA, Peters FT J Chromatogr A, 2004 , 169181.
7. Ramakrishna NVS, Vishwottam KN, Koteshwara MS,Santosh MM, Varma DP, $J$ Pharm Biomed Anal, , 2005, 39, 10061013.

8. http://www.emea.eu.int/pdfs/human/ swp/519902en.pdf .

9. http://www.fda.gov/downloads/Drugs/ GuidanceComplianceRegulatorylnformation/ Guidances/ucm079235.pdf.

10. M. Sun, L. Bai, and D. Q. Liu, Journal of Pharmaceutical \& Biomedical Analysis, 2009.49(2): p.529-533.

11. International Conference on Harmonization of Technical Requirements for Registration of Pharmaceuticals for Human Use (I.C.H.), Q2/R1, Validation of analytical procedures Text and methodology, 1995. 